\title{
Amyloid Beta A4 Precursor Protein- Binding Family A Member 1
}

National Cancer Institute

\section{Source}

National Cancer Institute. Amyloid Beta A4 Precursor Protein-Binding Family A Member

1. NCl Thesaurus. Code C104829.

Amyloid beta A4 precursor protein-binding family A member 1 (837 aa, $\sim 93 \mathrm{kDa}$ ) is encoded by the human APBA1 gene. This protein is involved in both the proteolytic processing of amyloid beta A4 precursor protein and neuronal vesicle exocytosis. 